\title{
Mesiodens: A Hospital Based Study
}

\author{
Senchhema Limbu, ${ }^{1}$ Parajeeta Dikshit, ${ }^{1}$ Sujaya Gupta ${ }^{1}$ \\ ${ }^{1}$ Kantipur Dental College Teaching Hospital and Research Centre, Basundhara Kathmandu, Nepal.
}

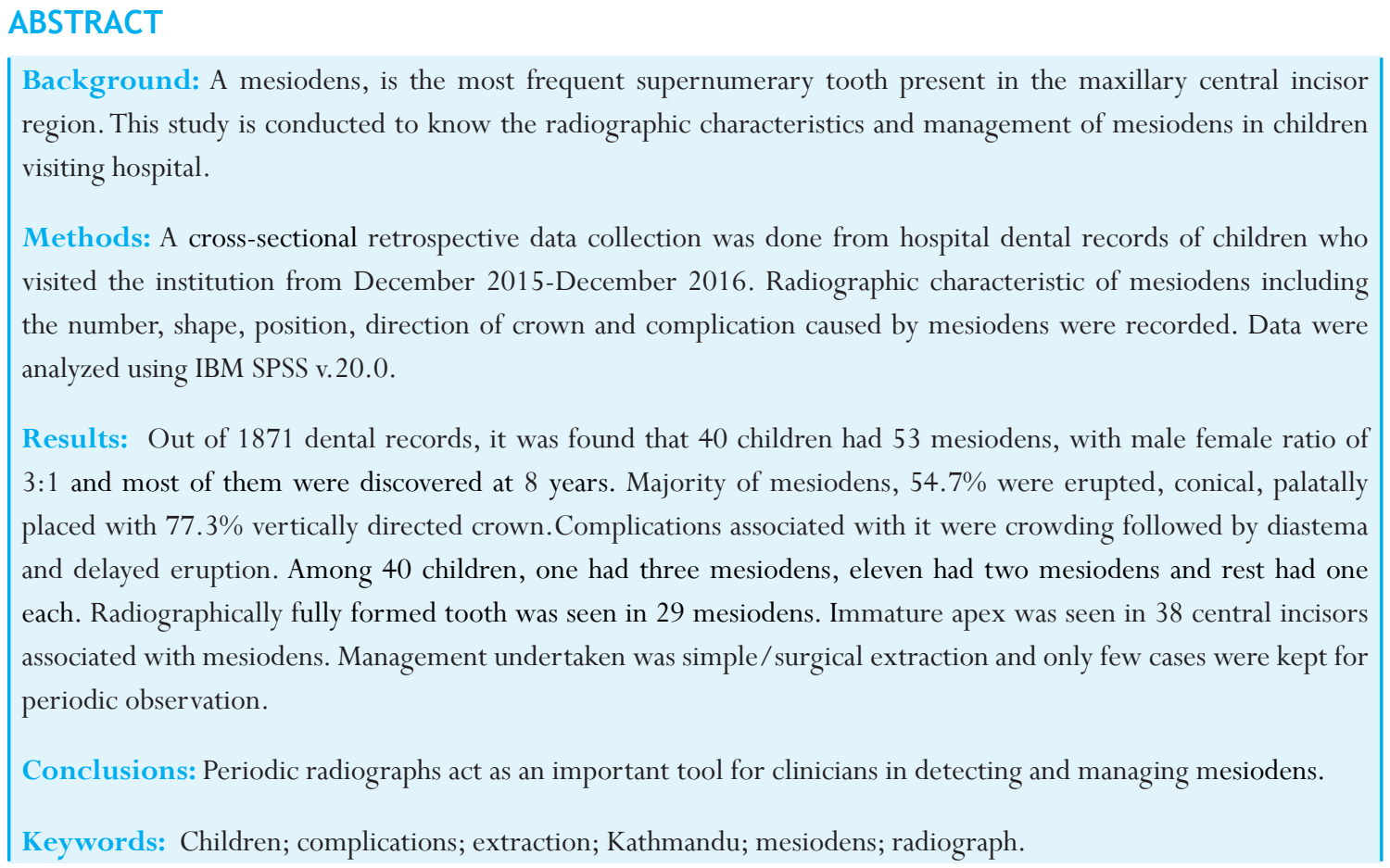

\section{INTRODUCTION}

A mesioden is most frequent supernumerary tooth present in maxillary central incisor region and can remain asymptomatic for years. ${ }^{1}$ Mesiodens may occur as single or multiple, unilateral or bilateral and may be erupted or impacted. There are two subclasses in classification of mesiodens. The first group is eumorphic teeth resembling central incisor. Second group is dysmorphic teeth categorized into conical, tuberculate, supplemental and odontomas. ${ }^{1-3}$ They are detected only if complications arise or noticed accidentally during routine radiographic examination. They might cause clinical complications like retention of the primary teeth, delayed/failure of eruption of permanent teeth, ectopic eruption, rotation of adjacent teeth, root resorption, abnormal diastema, formation of dentigerous and primodial cysts, hence requiring surgical or orthodontic intervention. ${ }^{1,4-8}$
This study was conducted to determine radiographic features and management of mesiodens in the Department of Pediatric Dentistry at Kantipur Dental college and hospital.

\section{METHODS}

A cross-sectional retrospective study was done that comprised data from non-syndromic patients aged 3-15 years who visited Pediatric Dentistry department at Kantipur Dental College and Hospital or routine dental check-ups from December 2015- December 2016. The data was collected from $1^{\text {st }}$ January $2017-30^{\text {th }}$ February 2017 after taking approval from institutional review committee. Either a periapical or panoramic radiograph, or both were examined in patients that had mesiodens or complications associated with mesiodens. All radiographs were manually studied by a single skilled dentist on a transparency projector under constant 
lighting conditions. In addition to gender and age distribution, the following characteristics were recorded about the mesiodens: (1) number; (2)morphology; (3) eruption status; (4)sagittal position; (5) direction of the crown; (6)complications caused by it;(7) maturation of the permanent incisors; (8)development status of mesiodens, and (9) management.

Data were analyzed using the IBM SPSS v.20.0 and results were tabulated. The differences between the groups were tested using the Chi-square test. The level of significance was set at $5 \%(p<0.05)$ with confidence interval at $95 \%$.

\section{RESULTS}

A total of 40 patients were diagnosed as having mesiodens from 1871 children dental records, of which $30(75 \%)$ were boys and $10(25 \%)$ were girls. The male female ratio was 3:1 and most of the mesiodens were discovered in the median age $8(8.19 \pm 3.045)$ years (Table 1$)$. A total of 53 mesiodens were detected, $43(81.1 \%)$ of which were seen in permanent teeth and $10(18.9 \%)$ were in deciduous teeth. Twenty nine (54.7\%) mesiodens were erupted and $24(45.3 \%)$ were impacted. Complications associated with mesiodens were crowding in $17(32.1 \%)$ cases, diastema in $14(26.4 \%)$ followed by delayed eruption in $10(18.9 \%)$ and $12(22.6 \%)$ patients were asymptomatic. Regarding sagittal position of the mesiodens, 35 (66\%) of them were palatally placed, $15(28.3 \%)$ were within the arch and 3(5.7\%) were buccally placed. According to radiographic position $41(77.3 \%)$ mesiodens were vertically positioned, $9(17 \%)$ were inverted and $3(5.7 \%)$ were horizontally placed. Most of the cases $28(70 \%)$ had 1 mesiodens, $11(27.5 \%)$ had 2 mesiodens and $1(2.5 \%)$ patient had 3 mesiodens. According to morphology, conical shape was the most common type 46(86.8\%), 6(11.3\%) were trabeculate and $1(1.9 \%)$ was supplemental. Out of these 53 mesiodens $7(13.2 \%)$ showed crown formation only, $17(32.1 \%)$ showed partial root formation and 29(54.7\%) showed fully formed teeth. Radiographically central incisor associated with mesiodens showed immature apex in $38(71.7 \%$ ) cases and mature apex in $15(28.3 \%)$ cases. The treatment modalities undertaken were, simple extraction in $29(54.7 \%)$ cases, surgical extraction in $19(35.8 \%)$ cases and $5(9.4 \%)$ cases were kept under observation depending upon placement of mesiodens and status of the permanent teeth (Table 2). Extractions were found to be statistically significant $(p<0.05)$ at age group 6-11 years(Table 3$)$.

Table 1.The frequency of mesiodens according to age.

\begin{tabular}{|l|r|r|r|r|}
\hline $\begin{array}{l}\text { Age } \\
\text { range } \\
\text { (years) }\end{array}$ & $\begin{array}{l}\text { Frequen- } \\
\text { cy }\end{array}$ & $\begin{array}{l}\text { Per- } \\
\text { centage }\end{array}$ & $\begin{array}{l}\text { Mean } \pm \\
\text { S.D. }\end{array}$ & $\begin{array}{l}\text { Me- } \\
\text { siodens } \\
\text { present }\end{array}$ \\
\hline $0-5$ & 367 & $19.6 \%$ & & $3(7.5 \%)$ \\
\hline $6-11$ & 1183 & $63.2 \%$ & 8.19 & $28(70 \%)$ \\
\hline$\geq 12$ & 321 & $17.2 \%$ & $9(22.5 \%)$ \\
\hline Total & 1871 & & & \\
\hline
\end{tabular}

\section{Table 2. Characteristics of mesiodens.}

Mesiodens characteristics

Frequency Percentage

(n)

(\%)

\begin{tabular}{|c|c|c|c|}
\hline Total no & & 53 & 100 \\
\hline \multirow[t]{2}{*}{ Gender } & Male & 30 & 75 \\
\hline & Female & 10 & 25 \\
\hline \multirow[t]{2}{*}{ Type of teeth } & Deciduous & 10 & 18.9 \\
\hline & Permanent & 43 & 81.1 \\
\hline \multirow[t]{3}{*}{ Number } & Single & 28 & 70 \\
\hline & Double & 11 & 27.5 \\
\hline & Triple & 1 & 2.5 \\
\hline \multirow{2}{*}{$\begin{array}{l}\text { Eruption } \\
\text { position }\end{array}$} & Erupted & 29 & 54.7 \\
\hline & Impacted & 24 & 45.3 \\
\hline \multirow{3}{*}{$\begin{array}{l}\text { Sagittal } \\
\text { position }\end{array}$} & Bucally & 3 & 5.7 \\
\hline & Palatal & 35 & 66 \\
\hline & Within arch & 15 & 28.3 \\
\hline \multirow[t]{4}{*}{ Complication } & Crowding & 17 & 32.1 \\
\hline & Diastema & 14 & 26.4 \\
\hline & $\begin{array}{l}\text { Delayed } \\
\text { eruption }\end{array}$ & 10 & 18.9 \\
\hline & Asymptomatic & 12 & 22.6 \\
\hline \multirow{3}{*}{$\begin{array}{l}\text { Morphology / } \\
\text { shape }\end{array}$} & Conical & 46 & 86.8 \\
\hline & Tuberculate & 6 & 11.3 \\
\hline & Supplemental & 1 & 1.9 \\
\hline \multirow{3}{*}{$\begin{array}{l}\text { Direction of } \\
\text { crown }\end{array}$} & Vertical & 41 & 77.3 \\
\hline & Inverted & 9 & 17 \\
\hline & Horizontal & 3 & 5.7 \\
\hline \multirow[t]{3}{*}{ Formation } & Only crown & 7 & 13.2 \\
\hline & Partial root & 17 & 32.1 \\
\hline & Entire tooth & 29 & 54.7 \\
\hline \multirow[t]{2}{*}{ Incisor apex } & Mature & 15 & 28.3 \\
\hline & Immature & 38 & 71.7 \\
\hline Treatment & $\begin{array}{l}\text { Simple } \\
\text { extraction }\end{array}$ & 29 & 54.7 \\
\hline
\end{tabular}


Surgical

19

extraction

Observation 5

$\begin{array}{lll}\text { Observation } & 5 & 9.4\end{array}$

\section{DISCUSSION}

Mesiodens may occur individually or in multiples which are termed as mesiodentes. ${ }^{8}$ In the present crosssectional retrospective study based on the hospital records, 40 patients showed the presence of 53 mesiodens. The male female ratio in present study was 3:1 which was similar to findings of other studies like, Kim et al., ${ }^{9}$ Asaumi et al. ${ }^{7}$ and Huang et al. ${ }^{4}$ that reported $4: 1,2.8: 1$ and $2.5: 1$, respectively. In this study, $81.1 \%$ mesiodens were present in permanent dentition which was in agreement with the findings by Ferres-Padro et al. $^{10}$

Mesiodens were most frequently seen in $8(8.19 \pm 3.045)$ years old children in this study (Table 1$)$. Similarly, Kazanci ${ }^{11}$ discovered largest number of mesiodens at 8-9 years and Asaumiet al., ${ }^{7}$ at 7 years. This period coincides with eruption time of maxillary central incisor and complications such as delayed eruption, crowding often leading to dental visits followed by radiographic examinations. Therefore it's logical that most mesiodens were discovered in this period. ${ }^{11}$

Most of the mesiodens in our study were erupted in $54.7 \%$ cases similar to study by Sulabha et al. ${ }^{12}$ and impacted mesiodens were $45.3 \%$ which was lower than other studies in literature. ${ }^{8,11,13}$ This may be explained by

Table 3. Age and Treatment of mesiodens.

\begin{tabular}{|c|c|c|c|c|c|c|c|}
\hline \multirow{2}{*}{$\begin{array}{l}\text { Age range } \\
\text { (years) }\end{array}$} & \multicolumn{2}{|c|}{ Maturation } & \multicolumn{2}{|c|}{ Dentition } & \multicolumn{3}{|c|}{ Management/ Treatment } \\
\hline & Immature & Mature & Permanent & Deciduous & $\begin{array}{l}\text { Simple Ex- } \\
\text { traction }\end{array}$ & $\begin{array}{l}\text { Surgical } \\
\text { Extraction }\end{array}$ & Observation \\
\hline $0-5$ & $3(5.7 \%)$ & $0(0 \%)$ & $0(0 \%)$ & $3(5.7 \%)$ & $0(0 \%)$ & $0(0 \%)$ & $3(3.7 \%)$ \\
\hline $6-11$ & 32 (60.4\%) & $4(7.5 \%)$ & $29(54.7 \%)$ & $7(13.2 \%)$ & $22(41.5 \%)$ & $12(22.6 \%)$ & $2(3.7 \%)$ \\
\hline$\geq 12$ & $3(5.6 \%)$ & $11(20.7 \%)$ & $14(26.4 \%)$ & $0(0 \%)$ & $7(13.2 \%)$ & 7 (13.2\%) & $0(0 \%)$ \\
\hline Total & $38(71.7 \%)$ & $15(28.3 \%)$ & $43(81.1 \%)$ & $10(18.8 \%)$ & $29(54.7 \%)$ & $19(35.8 \%)$ & $5(9.4 \%)$ \\
\hline
\end{tabular}

presence of large numbers of conical mesiodens which are more likely to erupt. ${ }^{13,14}$

von Arx et al. ${ }^{15}$ reported that majority of supernumerary teeth laid palatal to central incisors, similar to our result. The difficulty level increases in the labio-palatal impactions. Higher the impaction in the palate, less is the chance of damage to the apices of permanent teeth. Thus a careful surgical approach helps in removal of the supernumerary tooth without hampering the vitality of adjacent teeth. ${ }^{16}$

In present study, the number of mesiodens was one in $70 \%$, two in $27.5 \%$ and three in $2.5 \%$. Similarly many studiesreported single mesiodens. , $7,9,13,14$ In our study mesiodens shape was mainly conical (86.8\%)followed by trabeculate and supplemental. Conical was found to be the most common type in accordance with other studies. ${ }^{2,9,14,17,18}$ Tuberculate mesiodens are common in permanent dentition that rarely erupt but may cause delay eruption of permanent incisors while supplemental mesiodens are more commonly seen in primary dentition resembling tooth of normal series and are rarely unerupted supporting the findings of our study. ${ }^{1,4,7,14}$

In the present study, complications due to mesiodens were crowding $(32.1 \%)$ of central incisors followed by diastema

and eruption, but $12(22.6 \%)$ cases were asymptomatic. Similar finding was seen in study by Roychoudhury et al. ${ }^{19}$ Various authors have reported mesiodens causing displacement/rotation of the adjacent teeth in 28$63 \%$ of the cases and delaying or preventing eruption of central incisors in $26-52 \%$ cases..$^{1,2}$ These results also support the findings of the present study.

The direction of crown of mesiodens were mostly vertical followed by inverted and horizontal which was similar to that reported by Patil et $\mathrm{al}^{17}$ and Kazanci et al. ${ }^{11}$ The direction affects the management undertaken.

In the present study, 29 mesiodens showed fully formed teeth, 7 showed partial root formation and 7 showed crown formation only. This could be because, conical mesiodens is mostly diminutive peg-shaped and erupts as completely formed tooth because their root formation is ahead of or at an equivalent stage to that of the central incisor. ${ }^{1,14,17}$ The trabeculate mesiodens develops later and show delayed or incomplete root formation when compared with the adjacent teeth and often interferes with the eruption of incisors. ${ }^{17}$

Permanent central incisor radiographs associated with mesiodens showed immature apex in $38(71.7 \%)$ cases and mature apex in $15(28.3 \%)$ cases which is an important 
criteria for treatment planning to the clinician. Some treatment approach calls for late extraction of mesiodens when the adjacent permanent incisors have completed their root formation. ${ }^{20,21}$

Looking at the position of mesiodens and maturation of permanent incisors apex, there can be confusion about whether mesiodens should be extracted simply/ surgically or they should be retained and followed up radiologically. ${ }^{13}$ The management undertaken in this study were, simple extraction for 29(54.7\%), surgical extraction for 19 (35.8\%) and 5 (9.4\%) were kept under observation. Extractions were found to be statistically significant at age group 6-11 years. Similarly, Russell and others recommended extraction of mesiodens in the early mixed dentition stage to allow normal eruptive forces for spontaneous eruption of the permanent central incisors after the extractionthereby minimizing the need for orthodontic treatment. ${ }^{1,2,18,19,22,23}$ Hogstrom et al. $^{16}$ has suggested the removal of the mesiodens before the root development of the adjacent incisors is completed. However, surgical removal of a mesiodens in the primary dentition is usually not recommended because the surgical procedure could lead to the displacement or damage to the developing tooth buds. Another reason is that the primary supernumerary teeth generally erupt into the oral cavity due to the presence of the wide interdental spaces. ${ }^{24}$ Another treatment modality calls for late extraction of mesiodens when adjacent permanent incisors have completed their root formation. ${ }^{21}$ If mesiodens is asymptomatic, periodic follow-up is necessary. ${ }^{14,25}$ Whatever the complications may be, early diagnosis and extraction of a mesiodens is a must to prevent malocclusion and dental abnormalities. This holds true in most of the cases in our study where majority of the mesiodens underwent extraction.

\section{CONCLUSIONS}

Early detection of mesiodens is imperative to prevent complications leading to malocclusion. Radiographic examination on regular basis is highly recommended for early detection of it. Pediatric dentists should be aware in making a correct decision to prevent complications and timely surgical intervention because a significant delay in treatment can create the need for more complex surgical and orthodontic management. This study was conducted in limited population in Nepal, the authors recommend future research involving larger population.

\section{REFERENCE}

1. Primosch RE. Anterior supernumerary teeth- assessment and surgical intervention in children. Pediatr Dent
1981;3(2):204-15. [Pubmed]

2. Russell KA, Folwarczna MA. Mesiodens-diagnosis and management of a common supernumerary tooth. J Can Dent Assoc. 2003;69(6):362-6. [Pubmed]

3. Meighani G, Pakdaman A. Diagnosis and management of supernumerary (mesiodens): a review of the literature. J Dent (Tehran).2010;7(1):41-9. [Pubmed]

4. Huang WH, Tsai TP, Su HL. Mesiodens in the primary dentition stage: a radiographic study. ASDC J Dent Child. 1992;59:186-9. [Pubmed]

5. Zilberman Y, Malron M, Shteyer A. Assessment of 100 children in Jerusalem with supernumerary teeth in the premaxillary region. ASDC J Dent Child. 1992;59(1)447.[Pubmed]

6. De Oliveira Gomes C, Drummond SN, Jham BC, Abdo EN, Mesquita RA. A survey of 460 supernumerary teeth in Brazilian children and adolescents. Int J Paediatr Dent. 2008;18(2):98-106 [Pubmed]

7. Asaumi JI, Shibata Y, Yanagi Y, Hisatomi M, Matsuzaki H, Konouchi H, et al. Radiographic examination of mesiodens and their associated complications. Dentomaxillofac Radiol. 2004;33:125-7. [Pubmed]

8. Khandelwal V, Nayak AU, Naveen RB, Ninawe N, Nayak PA, Sai Prasad SV. Prevalence of mesiodens among sixto seventeen-year-old school going children of Indore. J Indian Soc Pedod Prev Dent. 2011;29:288-93. [Pubmed]

9. Kim SG, Lee SH. Mesiodens: A clinical and radiographic study. ASDC J Dent Child. 2003;70:58-60. [Pubmed]

10. Ferrés-Padró E, Prats-Armengol J, Ferrés-Amat E. A descriptive study of 113 unerupted supernumerary teeth in 79 pediatric patients in Barcelona. Med Oral Patol Cir Bucal. 2009;14(3):E146-52. [Pubmed]

11. Kazanci F, Celikoglu M, Miloglu O, Yildirim H, Ceylan I. The frequency and characteristics of mesiodens in a Turkish patient population. Eur J Dent. 2011;5(3):361-5. [Pubmed]

12. Sulabha AN, Sameer C, Umesh K, Warad NM. Mesiodens: A radiographic study among the children of Bijapur, India. J Adv Oral Res. 2012;3:15-9. [Link]

13. Gunduz K, Celenk P, Zengin Z, Sumer P. Mesiodens: a radiographic study in children. J Oral Sci. 2008;50:28791. [Pubmed]

14. Mukhopadhyay S. Mesiodens: A clinical and radiographic study in children. J Indian Soc Pedod Prev Dent. 
2011;29:34-8. [Pubmed]

15. von Arx T. Anterior maxillary supernumerary teeth: a clinical and radiographic study. Aust Dent J. 1992;37: 18995. [Pubmed]

16. Hongstrom A, Andersson L. Complications related to surgical removal of anterior supernumerary teeth in chrldren.ASDC J Dent Child. 1987;54:341-3. [Pubmed]

17. Patil S, Pachori Y, Kaswan S, Khandelwal S, Likhyani L, Maheshwari S. Frequency of mesiodens in the pediatric population in North India: A radiographic study. J Clin Exp Dent. 2013;5(5):e223-6. [Pubmed]

18. Zhu JF, Marcushamer M, King DL, Henry RJ. Supernumerary and congenitally absent teeth: a literature review. J Clin Pediatr Dent. 1996;20(2):87-95. [Pubmed]

19. Roychoudhury A, Gupta Y, Parkash H. Mesiodens: a retrospective study of fifty teeth. J Indian Soc Pedod Prev Dent. 2000;18(4):144-6. [Pubmed]

20. Mitchell L, Bennett TG. Supernumerary teeth causing delayed eruption--a retrospective study. Br J Orthod. 1992;19:41-6. [Pubmed]

21. Fernández Montenegro P, Valmaseda Castellón E, Berini Aytés L, Gay Escoda C. Retrospective study of 145 supernumerary teeth. Med Oral Patol Oral Cir Bucal.
2006;11(4):E339-44. [Pubmed]

22. Tay F, Pang A, Yuen S. Unerupted maxillary anterior supernumerary teeth: report of 204 cases. ASDC J Dent Child.1984;51(4):289-94. [Pubmed]

23. Witsenburg B, Boering G. Eruption of impacted permanent upper incisors after removal of supernumerary teeth. Int J Oral Surg. 1981;10(6):423-31. [Pubmed]

24. Solares R. The complications of late diagnosis of anterior supernumerary teeth: case report. ASDC J Dent Child. 1990;57:209-11. [Pubmed]

25. Rajab LD, Hamdan MA. Supernumerary teeth: review of the literature and a survey of 152 cases. Int J Paediatr Dent. 2002;12:244-54. [Pubmed] 